\title{
CORRIGENDUM
}

\section{Protective effects of noradrenaline against tumor necrosis factor- $\alpha$-induced apoptosis in cultured rat brown adipocytes: role of nitric oxide-induced heat shock protein 70 expression}

E Nisoli, L Regianini, A Bulbarelli, L Briscini, R Bracale and MO Carruba

International Journal of Obesity (2012) 36, 1593; doi:10.1038/ijo.2012.189

Correction to: International Journal of Obesity (2001) 25, 1421- The authors would like to apologise for this error. 1430

Since the publication of this paper, it has been noticed that the author name R Breacale has been listed incorrectly. The correct spelling is $\mathrm{R}$ Bracale. 